\title{
The role of the Support and Attention to Diversity Teacher \\ (SADT) from a community-based perspective: promoting educational success and educational inclusion for all
}

\begin{abstract}
This article addresses the transformation of the role of the Support and Attention to Diversity Teacher (SADT), traditionally called special education faculty. The results are from a qualitative study in three inclusive preschool and elementary schools in Catalonia, Spain. The results demonstrate a transformation in the role of the SADT that mobilizes teachers, specialists and diverse agents in the community to join the work of educational support. The transformation of the SADT role fosters an improvement in the attention and learning of children in the classroom, and existing resources are optimized in collaboration with the entire educative community.
\end{abstract}

Keywords: support teacher; inclusive schools; community-based support; academic success; support networks; teacher collaboration.

Abbreviations ${ }^{1}$

\section{Introduction}

The impetus shown by inclusive schools represents an investment in improving the efficiency of educational institutions and assuring the participation and the success of all students, particularly student groups at risk of exclusion and academic failure (Echeita \& Ainscow, 2011). These types of schools demonstrate the importance of collaboration amongst the various educational agents to generate more inclusive

\footnotetext{
${ }^{1}$ EAP: Sectorial team that advises several schools and institutions in the quarter or zone on special educational needs

CREDA: Team devoted to advising schools and supporting deaf students or students with language difficulties
} 
structures that eliminate barriers to learning and encourage the participation of all students (Ainscow, 2001; Booth \& Ainscow, 2002). Currently, scientific evidence demonstrates the value of serving all students in the classroom to ensure academic success (Cole, Waldron, \& Majd, 2004; Kalambouka, Farrell, Dyson, \& Kaplan, 2007) and reduce social inequalities (Hargreaves, 1967; Lucas, 2001; Rosenbaum, 1976). In an increasingly complex society, addressing diversity in mainstream schools has become a major issue not only because diversity concerns learning but also to build healthier societies (Orfield, Frankenberg, \& Siegel-Hawley, 2010). In this context, it is absolutely essential to rethink the role of the traditional special education teacher, in this article designated the Support and Attention to Diversity Teacher (SADT, or Support Teacher, to simplify) because the research and our experience demonstrate that this title better represents the functions that the Support Teacher performs.

\subsection{Educational support in inclusive contexts}

Traditionally, the concept of support has been associated with the idea of help, predominantly individually based, provided to students who, for various reasons, experience difficulties in following an educational process parallel to the process of their peers. It was assumed that these difficulties were primarily intrinsic to the student and required special education. The medical-clinical framework that extends from diagnosis to treatment permeated this model, and we mostly continue to pay for the results of this framework (Alborno \& Gaad, 2014; Bines \& Lei, 2011; Griffin, Kilgore, \& Winn, 2008).

Although we have not left this model entirely and do not have the means to understand and address learning difficulties, beginning with the inclusive school movement of the 1990s, the theory and practice of understanding the support provided 
and the role of the special education teacher was called into question (Ainscow, 2001). In an inclusive context, support cannot be viewed as an entity that is disconnected from the dynamics and purpose of the centre itself (Porter \& Smith 2008). Therefore, in this study, we understand educational support as a set of practices that act in two manners. On the one hand, there is the goal of eliminating the barriers to learning and participation that limit the progress of students (Boot \& Ainscow, 2002), particularly students belonging to the most vulnerable groups. Conversely, there is the goal of accelerating the learning of disadvantaged students (Levin, 1998; Slavin, Lake, Davis, \& Madden, 2011) and prioritizing the most relevant content for students who cannot manage the mandatory curriculum in its entirety, as may occur with students with intellectual disabilities.

The role of the SADT becomes more complex because of socio-cultural and interactive learning perspectives and their resultant difficulties, understanding that learning occurs by interaction and dialogue (Edwards \& Mercer, 1988; Mercer, 1997; Wells, 2001) situated in a particular social and cultural context (Bruner, 1996; Cazden, 1991; Lave \& Wenger, 1991; Rogoff, 1993; Vygotski, 1988;). Based on this premise, we understand that the role of the faculty is closely linked to the dynamics of the school and its environment. This understanding precludes considering this teacher to be an added element or a specialist foreign to the reality of the centre and the community in which the school is located, as indicated by recent research (Alborno \& Gaad, 2014; Bleach, 2013).

Scientific research recognizes that developing inclusive educational practices requires a "network of standardized support" (Muntaner, Alzina, \& Radó, 2006; Stainback \& Stainback, 2004). In an inclusive school, assuming that educational processes are driven by interactions, we can no longer consider the SADT to be the only 
figure who provides support. Moreover, an increasing number of findings indicate that the coordinated action of all agents who interact with the child is the best guarantee of providing effective support (Ault, Collins, \& Carter, 2013; Russell, 2008; Ryder, Rostas, \& Taba, 2014). Overcoming the barriers that limit such collaboration (Hodge \& Runswick-Cole, 2008) should be one of the first objectives of this type of support, including in the field of research (O'Brien, McConkey, \& Garcia-Iriarte, 2014). The network composed of these agents must comprehensively address the entire educational system, and their actions must not be focused exclusively on students with special educational needs but should seek to facilitate the participation and learning of all students.

\subsection{The Support Teacher in Inclusive Schools}

Various studies suggest that the roles of the SADT include teaching, advising, and management (Eiseman, Pleet, Wandry, \& McGinley, 2010; Takala, Pirttimaa, \& Törmänen, 2009; Vlachou, 2006). Thus, the relevant question is what type of context and from what perspective of attention to diversity are these functions developed.

Traditionally, the function of teaching was the only function considered for the special education teacher, with a focus on small groups of students, all with educational difficulties, outside the regular classroom and within school hours (Markussen, 2004; Takala, et al., 2009). This practice, which separated students by levels of learning and other forms of segregation, similar to the premature selection based on tracks, negatively affects the most vulnerable students because this practice increases and accentuates existing educational inequalities (Braddock \& Slavin, 1992; Oakes, 1985; OECD, 2012; author removed for peer review, 2013).

Thus, the function of the SADT may include more inclusive formats, developing itself principally within the mainstream classroom and directed at all students (Giné, 
Duran, Font, \& Miquel, 2009), working collaboratively with the tutor in a co-teaching modality. Various studies address the effect of co-teaching (two teachers in the classroom), which, among other benefits, renders it possible to support students who have more difficulty in the mainstream classroom, advise the general teacher on how to improve his/her praxis, and monitor the progress of students with learning difficulties or some type of disability in a mainstream context, thus achieving greater educational efficiency (Austin, 2001; Gurgur \& Uzuner, 2011; Huguet, 2006; Mastropieri, et al., 2005; Weiss \& Lloyd, 2002; Strogilos \& Stefanidis, 2015). That said, shared teaching presents new challenges for teachers. According to Strogilos and Tragoulia (2013), shared planning, specific training to prepare teachers for collaboration, and a good understanding and willingness to collaborate with other teachers are necessary.

Eisenman et al. (2010) observed that advising suggests accompanying the general teacher in the improvement of learning, teaching, and assessment strategies by mutual learning and negotiating that indirectly effects the improvement of the learning processes of students.

The management function includes participation in coordinating meetings among teachers, student assessments, the design of materials, the monitoring of students with more difficulties, and coordination with other stakeholders in the educational community (Takala, et al., 2009). To that end, according to the reviewed literature (Carpenter \& Dyal, 2007; Knackendoffel, 2005; Wallace, Anderson, \& Bartholomay, 2002; Eisenman, et al., 2010), the creation of formal structures that promote collaborative spaces between teachers are important, given that the good administration of these spaces affects student performance (Eisenman et al., 2010).

\subsection{Contextualization of the Catalan Educational System.}


The Catalan Educational System is regulated by the Education Law of Catalonia (2009), which promotes the right to a quality education and endorses attention to diversity to achieve equal opportunities. Different modalities of schooling are provided to students with special educational needs: mainstream school, shared schooling (when the student attends a mainstream school for a period of time and a special school for another period of time), or special education schools.

Regular schools are staffed with one or more special education teachers (SADT) whose mission is to attend to students' learning difficulties, giving preference to students with disabilities. Those schools that must attend to students with serious afflictions or extreme limitations to their autonomy have a Special Education Support Unit (USEE) with at least one special education teacher and one specialized teacher in addition to a supply of specialized materials.

The structure of the educational system in Catalonia is sectorized in such a manner that in each zone of the country (locality or neighbourhood in large cities), there is a Psychopedagogical Orientation and Advising Team (EAP) comprising psychologists, psychopedagogists and social workers. These individuals are responsible for providing diagnoses and orientation for students with special education needs (SEN) and for their families in addition to advising in the schools of their respective zones.

\subsection{Goals of the research}

In this article, we analyse the distinguishing features of the role of support teachers who develop their work in inclusive schools by adopting a community-based perspective, opening up to the community and emphasizing support for the quality of the interactions. In this manner, we expect to [1] identify the role of the support teacher in the individualized attention to students with greater needs when his/her intervention is inclusive, [2] further examine the support teacher's relationship with all of the other 
teachers at the school, and [3] delve into the relationships created between the support teacher and the educational community.

\section{Methodology}

To respond to these objectives, we conducted a qualitative study based on Communicative Methodology (Gómez, Latorre, Sánchez Aroca, \& Arrow, 2006), which is based on the need to overcome the epistemological gap between researchers and the other participants, teachers, families, and students who contribute their cultural knowledge derived from their own experiences (Oliver, de Botton, Soler, \& Merrill, 2011). A communicative research orientation draws on Habermas (2001) and his premise that a person is a subject capable of interpreting and reflecting on his/her own reality. Therefore, an understanding of reality is constructed in an intersubjective manner by egalitarian dialogue (Gómez et al., 2006) between academics, research subjects and group reflection. This methodological orientation proposes a transformation of reality by not only conducting research regarding the subjects but also conducting research with the subjects. This methodology incorporates the voices of all of the research participants throughout the entire research process (Gómez, Elboj \& Capllonch, 2013; Gómez, Puigvert \& Flecha, 2011).

Considering this premise, our research was developed within the framework of a Seminar on Educational Support comprising four researchers and 12 teachers and principals from some of the schools that were studied. The seminar began in the school year 2010-2011 with an in-depth analysis of the types of educational support provided in schools that were conducting an inclusive project. In the first year, needs and educational support strategies used in the various participating centres were analysed. Combined with this analysis, debates regarding literature about educational support 
were conducted. In the second year, cases provided by the centres were reviewed in conjunction with literature on the subject. In the third year, as a result of this review, the decision was made to create a research design in conjunction with the centres that participated in the seminar. The intention was to systematize and analyse as a group how educational support was being provided and identify and define the role of the SADT in the context of inclusive schools.

\subsection{Criteria for the selection of cases}

Of the schools that participated in the Seminar, three were chosen by the participants themselves to conduct the empirical research following five criteria: [1] Participants defined themselves as inclusive schools; [2] Participants promoted the participation of the community in different areas of school operations, including classroom activities (Author removed for peer review, 2005; Author removed for peer review, 2013); [3] Participants had students with disabilities; [4] The students as a group demonstrated cultural diversity; and [5] Participants had evidence of improved learning in all of their students. In one of the centres, we analysed the scores on results ${ }^{2}$ from internal evaluations, and in the rest of the centres, we considered the results of external standardized tests from the sixth level of primary education in the subjects of mathematics, Spanish, Catalan, and English from the 2008-2009 to 2012-2013 academic years. Thus, we considered that these schools had improved student learning if, despite great

\footnotetext{
${ }^{2}$ In one of the cases, we considered the internal evaluation of the school because that school had not undergone external evaluations because it was a new school and did not include the 6th grade of elementary school, the grade in which external evaluations are normally administered by the Catalonian Educational Administration. However, we were interested in including this school in the study because, from the time of its creation, this school had been dedicated to transforming the role of the SADT.
} 
diversity in their student body, their results indicated significant progress over the years.

\subsection{Schools selected}

The results presented gather evidence from three schools that offer kindergarten and primary education and that meet the established selection criteria by developing an inclusive school model with strong community participation (Author removed for peer review, 2013).

The L Education Centre is located in a suburb of the metropolitan area of Barcelona. During the 2013-2014 academic year, this school had a total of 465 students, of which 158 came from families from different nationalities (57 from Latin American countries and 101 primarily from sub-Saharan Africa). In the Centre, there were 16 students who had disabilities (Autism Spectrum Disorder [ASD] and intellectual disabilities), 58 students who had learning disabilities, and 89 students who received follow-up care and social services from the city. Figure 1 presents the evidence of improved academic results in the Centre from the 2008-2009 to 2012-2013 academic years.

\section{Figure 1}

School A is located at the northeast corner of Catalonia in one of the towns on the French border. During the 2013-2014 academic year, this school had 384 students, of which 120 belonged to families of other nationalities (58 from Morocco, 21 from Latin America, and the rest from various other nations, particularly Guinea, Romania, Nigeria, Senegal, and Pakistan); 68 belonged to Roma families. Of the total number of students, 13 had a disability or a severe behavioural disorder, and 97 received care and 
monitoring from social services. Figure 2 presents progress with respect to the academic results obtained in recent years.

\section{Figure 2.}

The third school included in the study is Centre V, which is located in a small city in the metropolitan area of Barcelona. During the 2013-2014 academic year, Centre $\mathrm{V}$ had a total of 290 students in elementary and preschool, of which 17 children were from immigrant families, particularly from the Maghreb countries, with the remainder coming from Africa and Tunisia. Nine students were diagnosed with a disability, and 9 students received monitoring from social services. Because this school did not yet include 6th grade, there was no access to external standardized assessments. The improvements in learning were validated using internal statistical reports concerning the subjects considered in the selection of the centres.

\subsection{Instruments}

For data collection, various qualitative instruments were adopted: in-depth interviews, communicative discussion groups, and document analysis of the minutes from the Seminars on Educational Support. The use of different instruments and sources of information contributed to the triangulation of the data, which enriches the results at the qualitative level in addition to increasing the reliability of their interpretation (RuizOlabuénaga, 2009).

The in-depth interview scripts and the communicative discussion groups were constructed in the Educational Support Seminar with the aid of the seminar participants. With those participants, we defined the objectives and agreed on the three primary research themes: support agents, SADT profile and types of support. Next, we turned 
the themes into questions and constructed a first draft of the instruments, which were then reviewed and approved in the seminar.

\subsection{Data collection}

The following table summarizes the relations among the instruments that were used and among the people who were involved. As seen, the decision was made to conduct an in-depth interview with the schools principal. Our intention was to obtain a more in-depth perspective regarding aspects of management and support organization throughout the schools. We also used in-depth interviews with the support teachers (SADT) of each school. This technique was selected because there are only one or two assigned support teachers, hence the benefit of conducting in-depth interviews.

Understanding support from a community perspective can enable the entire community to be its own agent; therefore, we decided to conduct discussion groups. The discussions were between teachers and tutors who collaborate closely with the SADT and who are in charge of the classrooms with students with difficulties. Discussion groups were also conducted with the families because we were working with schools in which families participate in the students' learning process. Finally, discussion groups were conducted with the students themselves. Each group comprised both students with difficulties and students without difficulties.

Finally, we conducted an analysis of the documents of the proceedings of the support seminar meetings of the three courses that preceded the development of the fieldwork. Therefore, a total of 5 interviews and 9 discussion groups were conducted, and 26 document proceedings were reviewed throughout the three selected schools

\section{Table 1}

For data collection, we considered the ethical aspects presented by the European Commission (European Union, 2010). We have maintained the anonymity of the 
participants using pseudonyms and confidentiality. We also required informed consent to participate in the study as well as the consent of the parents or legal guardians of minor participants. Furthermore, each step in the research process was agreed upon and reviewed by the teachers in the participating schools within the Seminar framework. This process guarantees that both the process and the results obtained are carefully treated to reflect the multiple views of reality.

\subsection{Data analysis}

To analyse the data, we used thematic content analysis based on categories (Bardin, 1986) using the Atlas-T1 v6 program. When constructing the categories, we prioritized the areas that were considered when designing the various instruments. The transcriptions of some of the interviews and group discussions were selected, and a pilot analysis was conducted using these initial categories. By inductive reasoning, subcategories emerged from this first analysis. The table of categories and subcategories was subjected to review by the Seminar where, together, we defined each of the categories and subcategories to reach consensus on shared meaning. An understanding of the definitions of the categorical system was then internally validated with the aid of the research team: three team members and three pre-doctoral researchers who aided in the analysis and separately categorized the same fieldwork fragments to verify the closeness of agreement among their categorizations and adjusted the designated meanings of the different categories and subcategories accordingly. This step was conducted before the definitive data analysis. From this process, the definitive table of categories presented in Table 2 emerged.

\section{Table 2}

A total of 42 subcategories were included in each category. The table presenting the 42 subcategories is included as an appendix to the article. The coding by category 
results was presented in the Seminar, and with all of its participants, we finished reviewing and validating the interpretations of the results. The functions of the role of the SADT were identified as they emerged in the analysis of the various categories and are presented in the results in this manner.

\section{Findings}

In accordance with the objectives established in Point 1.4 and the information organized within the categories and subcategories (see annex), we have organized the results to consider the functions assumed by an SADT in an inclusive school related to [1] how specialized and individualized care is transformed into integrated care in the classroom, [2] how this type of inclusive support generates a new context and collaboration among all teachers, [3] how community participation in educational support tasks requires the SADT to be responsible for the coordination of this network of community support, and [4] how this support model affects learning. This organization allows us to use categories of analysis as crosscutting themes for the four previously mentioned themes, which we develop below.

\subsection{Support agents in the classroom}

The results of the fieldwork allow us to identify some of the characteristics of the care offered by the support teachers that coincide in the three schools. One of the characteristics concerns the space and time required for the care of students with special needs. In these centres, individualized care is moved into the mainstream classroom, which implies bringing the specific resource to the student with needs, not bringing the student to the resource, as is tradition. 
T: My resource is always...inside of the classroom, always, always, attempting to continue to adapt...in whatever way, to what the others are doing (Support Teacher interview, School A).

All participants in the study show us that support teachers participate in the mainstream classroom as one more human resource, which has consequences for the mainstream dynamics of the classroom, caring for all students. The implication is that there are no general teacher students and no SADT students but that all students are considered the responsibility of all teachers.

I: What abilities do you think are most important for a support teacher, a special education teacher, from the point of a view of a learning community like the one we are in?

P: Well, let's see, I think it's very important to be open to proposals and to be very clear on your function, that they are not your children but everyone's children, no longer for the special education teacher but for the entire faculty. So, to be very clear that the objective is that each boy and each girl must learn the maximum possible, we cannot place limits on them. I think it's very important that this is clear not only to the support teacher but also to everyone (Principal interview, School V).

The collected data indicate that the three centres studied give priority to the SADT's being present in the instrumental subjects such as language and mathematics. In this manner, the SADT acts as reinforcement to care for and help all of the children in the classroom and, in particular, to provide help and advice regarding the help required by students with more difficulties. The support teacher from Centre $\mathrm{L}$ describes her task as follows:

ST: Spaces in the schedule that permitted this type of individualized care were sought out and always [with an emphasis] from within the classroom. We also sought that, if the rest of the students were doing language and mathematics, the student with needs was also working on language and mathematics (Support Teacher interview, School L). 
Incorporating two teachers in the classroom renders it possible to prioritize work in small heterogeneous groups, as shown by the three analysed centres. This resource enables dividing the work into small groups using the criteria of heterogeneity and favouring more individualized care. This resource also permits diversifying the support that students with more difficulties receive, as we see below. In this context, the majority of the participants in the study identified that one of the tasks of the SADT is to promote interaction amongst students, moulding them and enabling them to be agents of support for their less capable peers.

ST: What do I offer the students? I think it's not so much what I offer the children with more difficulties, but what I offer everyone. Of course, one student may have more difficulty with addition, but another may have difficulty sharing, even if that student knows how to add or subtract decimals. Therefore, the support teacher, based on the type of activity that is already programmed and coordinated with the general teacher, has a more supportive function to generate activities for the students to learn amongst themselves (Support Teacher interview, School A).

With regard to this latter aspect, the fieldwork suggests that students with more difficulties prefer not to receive help specifically from the support teacher because such help may indicate that the student has a difficulty. The student prefers his/her own group of peers to provide the support that he/she needs to complete the task. We have gathered some evidence that indicates that this scenario has occurred. A general teacher describes this situation as follows:

T1: This type of student does not like to be helped in a personalized manner. The student feels better when it is the group itself that helps him/her, more than any other reason because the student does not want to feel different from the others. The student does not want someone to be at his/her side because he/she prefers to receive help from someone going around to each class helping everyone (General Teacher discussion group, School V). 
The fact that the SADT is working in mainstream classrooms does not cause the SADT to cease performing a task that is also conferred by his/her colleagues and that concerns the detection and initial evaluations of students with greater needs. Teachers stress that the work of the SADT in mainstream classrooms in a standardized interaction context enables the SADT to develop greater knowledge of the students with more difficulties. This process also allows the SADT to learn the teaching and relating styles of the general teacher, facilitating the identification of barriers to learning and participation that occur in that context and, therefore, allowing the SADT to be able to adapt the most appropriate help.

ST: Let's think about this case: the general teacher who sees that a certain situation is not working. I make an observation inside the classroom, taking advantage of the fact that I am already there, because I frequently enter the classrooms. I watch the general teacher and then share my observations with the person from the EAP (Psychopedagogic Advisory Team). Here, we evaluate whether we do a referral to the EAP. In this case, with the general teacher, we fill out the referral forms and coordinate the required interviews with the family (General Teacher discussion group, School V).

All participants at the three centres agreed that emphasizing the involvement of the SADT in mainstream classrooms allows him/her to be key in monitoring the students and families who require long-term support because the SADT knows the family history. Therefore, it is the SADT who makes the connections between the general teachers from one year to the next and coordinates follow-up with external professionals when required. Therefore, although general teachers change over the course of schooling, the SADT is the consistent mentor throughout primary education. 
MA: I am with this child from the beginning, intervening in the classroom with the interviews with the families and with this connection to the family. And the person who has been changing is the general teacher. In this case, no, because the general teacher has remained in the same group during two classes, and this has been one of the things that has helped the child: the consistent general teacher during two back-to-back classes (Support Teacher interview, School L).

\subsection{Interactions between teachers and collaborative work}

Bringing support to the mainstream classroom calls for the studied centres to have more than one adult in the majority of subjects in a shared teaching situation.

Similar to the support teachers, many of general teachers in our study indicated that the actions teachers implement are related to the creation of materials and the design of strategies to work with students. This collaboration's principal premise is to advise the general teachers on how to adjust educational support for students with difficulties so that such support is as standardized as possible. One of the support teachers from Centre L illustrates this point as follows:

MA: All of the support for the general teachers is given in the moments that we have. We prepare materials; the general teacher is helped by adapting the individualized plans (Support Teacher interview, School L).

Many of the interviewed teachers agreed on the importance of valuing coteaching because co-teaching generates processes that improve teacher performance itself. The SADT relates in a particular manner to students with more difficulties, offering guidelines to the general teacher on how to approach the learning process and the relationship with those students, in many cases by modelling.

ST: In an indirect way, there is very strong modelling in the classroom. When we come in and work, [the general teacher] learns from the manner in which we give instructions, the indications, how we treat and orient the children. After working in 
the classroom, we notice how the general teacher changes (Support Teacher contribution, School L, Meeting Minutes).

The relationships with families are one of the tasks that generate more difficulties amongst the teachers. Many SADT participants in this study demonstrated that the collaborative tasks with the general teachers include providing advice and helping to address certain questions in meetings with families. One of the support teachers from Centre L expressed the following:

On occasion, they ask us [the general teachers] to organize a meeting with some families on a specific topic that they do not know how to address. On some occasions, we participate in the meeting; it depends on the topic, on how sensitive it is (Support Teacher contribution, School L, Meeting Minutes).

Families also reported that problems exist that limit attempts to achieve better collaboration between families and teachers and collaboration of a broader scope. Families noted problems with communication and trust within the school's community model:

F1: I don't think that the lack of volunteerism is that related to parents' lacking information. Rather, parents and teachers don't truly believe that this can really benefit children .../... Many parents, and, I believe, even some teachers, think that this is a trend or that it doesn't directly benefit students. I think that this is what needs to be transmitted to families: that this really works, that it is scientifically based and that if people really get involved... what angers me is that the message doesn't get across because it is so simple that, well, it just has to be believed (Family discussion group. School V).

The collaboration among teachers is not limited to the classroom. In different manners, the three centres managed to procure time for reviewing cases and organizing support, which tends to engage the participants in the process of student learning. These 
short meetings, during which those cases that seriously concern teachers are analysed, are essential for developing more profound knowledge regarding the student and for articulating effective and coordinated educational support.

MA: In "Parlem de nens" ["Talking about Children", a coordination meeting], we have (...) meetings of communities or cycles. All of us who are involved with the child participate. This way, we all know the strategies utilized and the child's needs, given that the people who are going to be involved need to know the why (Support Teacher interview, School L).

These gatherings not only have an organizational, functional, or instrumental purpose but also emotional components, acting as oases of stability and support in the face of the discomfort generated by situations experienced by teachers in the classrooms. These meetings are coordinated and led by the SADT.

"Parlem de nens" is going very well because it relieves anxiety, discomfort from the general teachers over having the assessment meetings during the trimester. It helps the teachers have a comprehensive vision; that way, the general teacher knows how the English Specialist views the child, for example, how the student behaves with the specialist, how the student is viewed by others, and the specialist and general teacher make agreements on how to work together (Support Teacher interview, School L).

\subsection{Organisation of Community-Based Network for Educational Support}

The three institutions agreed to involve the entire school community, assuming that educational support is the task not only of teachers but also of other external agents: families, other volunteers, and alumni. Both the directors and the teachers interviewed focused on the importance of the diversity of interactions to promote student learning. Having the entire educational community be agents of educational support not only improves student learning but also counteracts the 
fears generated by including children with disabilities in school. Participating families describe this phenomenon as follows:

F1: [The involvement of the community] allows for the creation of another type of educational system. The fact that they can do workshops or learning stations that in other schools are not possible because of staff shortages. But here, you can have parents, interns, or even other volunteers come in. You can do other activities that, in other schools, are not possible.

F2: Personally, I'm happy because, the first year, I was scared since my child is a special education student and was afraid of being rejected by the other students, being somewhat on the margins. The truth is that with the natural way that everything has happened, my child has never felt special or rejected, and to be honest, I'm really happy about this (Family member discussion group, School V).

In partnership with families, the majority of teachers work to generate support mediated by high expectations for students and their families.

ST: Something we haven't said and that perhaps is one of the things that you can't see, but that is the hardest to work with, is expectations. We should never lose sight of them. We should never stop trusting that the child will give his/her best. [...] I remember a mother whose child was in the $1^{\text {st }}$ grade, who, throughout the entire year, asserted, "My child will not read, he/she will not be able to read". We would say, "Your child will read, we should do the work so that he can learn to read". And, of course, the child reads (Support Teacher interview, School A).

In this sense, we have observed that the SADT largely functions as a promoter and coordinator of the support network that is generated with the participation of other agents. Simultaneously, this collaboration has an empowering effect on families that participate as volunteers and are aware of the importance of their actions:

The fact that you work with [the school] makes it so that, for the child, studying or reading or doing things that are related to school is not a punishment because mom, 
dad or even grandma does it too. So I say to myself, does this help the child learn?

Of course it does! (Mother in discussion group. School V).

During our fieldwork, we were able to gather many statements such as this one. Such statements demonstrate that parents who volunteer increase the possibility of being able to help their child at home. Furthermore, many note the personal benefits derived from volunteering.

The three schools have volunteers who are families or other community members involved in the classroom in the teaching and learning processes of children. Specifically, the volunteer participates in the interactive groups (IGs) (Author removed for peer review, 2015; Valls \& Kyriakides, 2013). This action involves the creation of small heterogeneous groups in regular classrooms, incorporating volunteers. Normally the volunteers create four groups, each comprising approximately four to six children. Each volunteer takes his or her place in the class in an activity that was previously designed by the teacher. The groups of children rotate between different volunteers, spending approximately 15 or 20 minutes with each volunteer so that by the end of the session, each group has performed the four activities. The volunteer's mission is not so much to direct the activity, which the children are already familiar with, as it is to stimulate the children, ensure that none of the group members are left behind (encouraging the children to help one another) and control time. For example, if the session is a mathematics session, one activity could be numbering, another could be making change (mental calculation), another could be problem solving and a fourth activity could be geometry. In this context, the support teacher intervenes just like any other teacher able to observe the student with disabilities or learning difficulties while the latter is performing regular classroom activities. The support teacher helps the 
student directly or through his/her classmates. In terms of educational support, one quality of IGs raised by the volunteers is that the IGs are designed not to require adjustments for any of the students; all students perform the same activity:

ST: An interactive group has never been adapted to a student. We have not adapted an interactive group to anyone, ever. Adapt the activity itself, no, because it would be pointless (Support Teacher interview, School L).

The SADT advises on the design of the IGs, particularly when a child requires special support. The collaboration of the IGs facilitates learning, as reported by the children from School V.

S1: A grandmother of a girl comes to help the interactive groups in our classroom, and she helps us a lot because she has a way of explaining things and the teacher has another, and if we do not understand the teacher, maybe we understand her better (Student contribution, discussion group, School V).

All SADTs interviewed reported that the participation of family members and volunteers in the classroom not only improved learning but also promoted good relationships among families and increased their expectations and the motivation of the students themselves. This phenomenon is explained by one of the support teachers from

\section{Centre L:}

ST: For example, the mother of a classmate of your child, even if he/she is not a buddy, can say, "How fantastic your child is when I go to class, doing this and doing that". This has an impact; it directly affects them, and the students like this. In addition, they strive even more (Support Teacher interview, School L).

These strategies are also recognized by the families:

F1: The fact that a kid has to explain to another person, to another kid, whatever thing he/she knows, it helps the kid learn it better and also helps the one who is 
doing the explaining. One of the things that these groups have always inspired in children is trying to teach others. That's what we talked about before: the groups are made for this, to help each other (Family member discussion group, School V).

Accordingly, it follows that educational support is not only a task belonging to a trained professional but is also integrated into the dynamics of the centre in a standardized manner. Support Teachers agreed that understanding between the administration and the general teachers facilitates the realization of this model of support and that it should be shared with the entire educational community.

ST: To convey to this school's employees, teachers and guardians this enthusiasm for wanting to give a good response and help students by transmitting to them the same excitement that I have $[\ldots .$.$] because, in reality, it's really not my own personal$ work but that of the whole school (Support Teacher interview, School V).

In addition, the SADT and general teachers report that management actions and follow-up with external services are important. The complicity of educational administration is essential in a project that, without suppressing the school's traditional structure, brings with it changes to the traditional function of the SADT and considers the presence of volunteers (including family) in the school's daily teaching activities.

Furthermore, the SADT is responsible for management work and contact with external services. The entire team should be familiar with all of these tasks, given that certain functions to which we have referred are less "visible", as one of the support teachers interviewed declared:

ST: The thing is that the work for the students is not always directly for the student but done through working with all of the agents, with the family, and with the general teacher. Much of our work is with the general teacher and also ends up being with the specialists, .../... and all of the external adults like the EAP, CREDA (Educative Resources Centre for Audition Disabilities), social services, centres, 
psychologists, psychiatrists, private, public, city hall, well, whoever (Support

Teacher interview, School L).

\subsection{Learning effect}

The educational support model that we espouse here and the functions of the SADT are justified by the learning improvement of all constituents. For this reason, we believe that it is advisable to contribute information that helps us to better understand students' progress, particularly the progress of students who have greater difficulties.

When the SADT understands and fosters support as a "distributed" task in which other students, families and other volunteers can participate, the possibilities for help multiply, benefitting everyone's learning. A student noted some of the causes of learning improvement, innocently creating an outline:

S: We learn more [with more adults in the classroom], first, because they help the teacher and also because to us kids, we think it's really good. And we learn more. If the teacher is working alone, we learn $10 \%$ less, and if there are two teachers it would be $10 \%$ more and so on, each time faster and faster, faster, faster (Student contribution, School A).

However, we do not believe that an increase in the number of adults in the classroom in itself explains children's progress. When other members of the community participate in providing support, the students see their culture, including their language, better reflected in school. This participation constitutes an instrument that facilitates learning.

S: With [volunteer presence], we do better because they help us more. Well, the teachers help us too. But not only the teachers. They [the volunteers] help us too. Maybe we understand more the way they explain things than how the teacher 
explains things. For example, the teacher explains a problem to you and you don't understand. And then the person who helps us explains it to you and you understand it better (Student contribution, School V).

Families, particularly the families of students with greater difficulties, are quite aware of the school's inclusive nature and of the advantages that such inclusion gives their children in their personal growth and learning. This benefit was expressed by a mother whose son was diagnosed with ADHD, epileptic crises and severe learning difficulties when she was requested to assess the support received from the school:

F: As I already mentioned, my son is in special education. When he started, he was a baby and, truthfully, little by little, the change he has undergone (and his teachers have told me this as well) has been a good change. I see this at the formative level as well as in his maturity. It's true that he is very childish. But given the problems that he has, this is normal. But it is true that both in his ability to adapt and his education there has been an incredible change (Mother's contribution, School V).

The inclusive environment is generated by support that is always integrated in the classroom and by the impetus that comes from the collaboration of families and the community and translates into the value of solidarity amongst the students themselves. An example of this solidarity can be seen in the declaration of a girl who decided to broaden the support that she offered to a classmate diagnosed with a mild intellectual disability.

S: A girl who sat in front of me, she had trouble studying and everything. So one day I said to her, "Come on, I am going to work with you". And during recess they let us stay in the classroom, and I would help her study and I gave her advice so that she could get good grades (Student discussion group, School V).

It is extremely important that the families themselves are aware of the value of this solidarity both for the students who receive help and the adults and children who provide that help. A mother expressed this: 
M: The fact that a child has to explain to another person or child whatever he/she knows makes him/her learn. .../... So that the child might try to teach the other, this is what we talked about before in the group. It is done this way so that they might help each other (Mother in discussion group, School V).

All of the above, however, does not prevent faculty from noticing situations in which learning barriers are difficult to overcome. This situation occurs with students who begin school at an advanced age, without the benefits of previous effective schooling:

When a child in the 5th grade comes to you [10 years old or older, in Spain elementary school goes up to 6th grade] who has just arrived from his country of origin and has not had the opportunity to attend school; then you don't have time. Even though you are there - and we are there! - not much can be done (Teacher, discussion group, School L).

\section{Discussion}

The results show us that individualized attention to students with special needs inhabits a sociocultural context that includes the students in the standardized learning process. Instead of mobilizing students with difficulties towards specialized resources, the specialized resources seek out the students. This phenomenon represents a paradigm shift in which difficulties are not attributed to the children but in fact have much to do with the students' educational and social context. From this position, it is possible to overcome the barriers to learning and participation that affect this most vulnerable population (Ainscow, 2001; Booth \& Ainscow, 2002; Echeita \& Ainscow, 2011).

The fact that educational support is performed within the classroom generates co-teaching spaces in which we observe significant benefits that are consistent with what we observed in the scientific literature (Austin, 2001; Gurgur \& Uzuner, 2011; Huguet, 2006; Mastropieri et al., 2005; Strogilos \& Tragoulia, 2013; Strogilos \& 
Stefanidis 2015; Weiss \& Lloyd, 2002). However, one of the most significant results of our research is the finding that the presence of SADTs in the classroom constitutes a support model that general teachers and peers can provide. In our cases, the implication is a training process for all participants of this educational space.

The sociocultural and interactive learning perspective of the schools studied takes them beyond co-teaching or collaboration between professionals. In the same manner that teachers understand learning to be a complex process of interactions that extends beyond school (Bruner, 1996; Lave \& Wenger, 1991; Vygotsky, 1988), teachers perceive that learning barriers and, moreover, the overcoming of these barriers has much to do with these interactions and with the possibility of enriching collaboration with the school's initiative. For this reason, our results emphasize the decentralization of educational support from its specialist and isolated element (Tutty \& Hocking, 2004), distributing the responsibility of supporting all of the people involved in the learning processes of children: the general teacher, peers, the support teacher, families, volunteers, and other social agents.

The results indicate that in this model, the SADT acts as a promotor and coordinator of community-based educational support that empowers families and other agents by giving them a proactive, supportive role. This distributed perspective of educational support extends beyond the classroom space and is far from being the administrative role that was previously attributed to the support teacher (Eiseman, et al., 2010; Takala, et al., 2009; Vlachou, 2006).

The characteristics of our research do not allow us to establish a cause and effect relation. However, our research does confirm the good academic global results in three schools that have adopted, at least within the last five years, this inclusive support model and the profile of the SADT that we have described. We have also been able to 
confirm by qualitative analysis the beneficial effects of the model amongst students with greater difficulties or disabilities. This combination of roles of the SADT changes the vision of educational support and school organization and provides a strong impetus to improve learning for all students. The participation of the community from a position of solidarity leads to better results, as shown by numerous studies (Apple \& Beane, 2007; Bruner, 1996; Graden \& Bauer, 2004).

Ultimately the roles of the support teacher detailed in our research include teaching, advising and management, consistent with other investigations (Eiseman, et al., 2010; Takala, et al., 2009; Vlachou, 2006). When the educational support offered is inclusive, the role and functions assumed by the SADT evolves to include advice and support for the task of teaching that extends beyond the traditional understanding of educational support from a clinical-medical model (Alborno \& Gaad, 2014; Bines \& Lei, 2011; Griffin et al., 2008). Thus, the role of the SADT extends beyond the walls of the classroom to the entire school, with support becoming everyone's responsibility. This model suggests understanding that all children, regardless of their circumstances, deserve the best education (Stainback \& Stainback, 2004) and that an inclusive educational context should also be sustained within these parameters of success for all.

This study presented some limitations. It was conducted in three schools that have what is clearly an inclusive vision of support and community participation. These schools had been working for 3 years in the seminar in which we analysed these contents in depth. We believe that our work is an example of the good results that can be obtained from the vision presented here regarding the functions of the SADT. However, to generalize this profile, the model should be tested in other contexts.

However, this being a qualitative study, the extrapolation of its results can only be based upon a profound and idiosyncratic understanding of the analysis of the three 
centres. This understanding can prove quite useful for the improvement of educational support in other contexts.

As a final limitation, two of the schools studied demonstrated the global improvement of their academic results by external testing; in the third school, we were limited to the use of internal indicators (because of its recent creation). As was previously stated, we were quite interested in including the third school in the study because this school is one of the centres that has worked the most on developing and transforming the role of the SADT. However, we must acknowledge the lack of external evaluation of the third school as a limitation of this study.

\section{Conclusions}

This research has allowed us to identify the change from teacher support to the SADT, a situation that occurs within a community paradigm of participating schools. In this context, the work of the SADT includes, as a component of its core functions, being integrated into mainstream classroom teaching, counselling and collaboration with all of the teaching staff as well as the management and coordination of a job network that is focused on promoting inclusive educational support.

In this community context, one of the important tasks performed by the SADT is to promote interactions among all members of the community, thus promoting the educational support network in which the entire community (general teacher, support teacher, students, families, volunteers and other community members) is incorporated as support staff. These various support staffs participate in regular school activities, including educational activities in the classroom, thereby facilitating standardized quality attention for all students and avoiding moving students with difficulties to specialized resources or individual attention outside the classroom. Networking 
management also implies coordinating with institutions from outside and with families that require special monitoring.

SADT intervention within the regular classroom allows shared teaching and accompanying the general teacher in addressing the diversity of all students. Their participation in the classroom can provide direct support to students with the most pressing problems and facilitates the detection and initial assessment of the difficulties shown by the students as well as identifying barriers to learning.

The conclusions of our study have obvious implications regarding the perspective of the duties and role of the SADT in regular school but also for SADT training. We have noted the implications with our triple perspective of the SADT's role, which includes teaching, collaboration with regular teachers and leadership in the support network comprising all of the agents who are able to intervene. The implications of our study for the training of these specialized teachers are many and should be the focus of a separate study. In our context, however, two of these implications appear to be particularly relevant. The first is that the training of these professionals should place much more importance upon social and leadership skills. These skills are absolutely necessary for their work with the schools' teachers, with families and with the rest of the educational community. The second implication is that the proper preparation of these professionals should begin with solid training as teachers followed by specialization at the graduate level. We know that in the majority of European Union countries, such training is accepted. However, such is not the case in Spain, in which the required training is only mentioned within the description of teacher training and does not even amount to thirty credits (ECTS, it implies 750 hours of specific training). The functions described in our study, primarily advising other 
teachers and leadership in the support network, require training and even previous experience as a regular teacher.

\section{References}

Ainscow, M. (2001). Desarrollo de escuelas inclusivas. Madrid, España: Narcea.

Alborno, N. E., \& Gaad, E. (2014). 'Index for inclusion': A framework for school review in the United Arab Emirates. British Journal of Special Education, 41(3), 231-247. doi: 10.1111/1467-8578.12073

Authors. (2015). [details removed for peer review]

Apple, M. W., \& Bean, J. A. (2007). Democratic schools: Lessons in powerful education. Postsmouth, N.H: Heinemann.

Ault, M. J., Collins, M. C., \& Carter, E. W. (2013). Congregational participation and supports for children and adults with disabilities: Parent perceptions. Intellectual and Developmental Disabilities, 51(1), 48-61. doi: http://dx.doi.org/10.1352/1934-9556-51.01.048

Austin, VL. (2001). Teachers' beliefs about co-teaching. Remedial and Special Education, 22(4), 245-255. doi: 10.1177/074193250102200408

Bardin, L. (1986). El análisis de contenido. Madrid, España: Akal.

Bines, H., \& Lei, P. (2011). Disability and education: The longest road to inclusion. International Journal of Educational Development (31), 419-424. doi:10.1016/j.ijedudev.2011.04.009

Bleach, J. (2013). Improving educational aspirations and outcomes through community action research. Educational Action Research, 21(2), 253-266.

Booth, T. \& Ainscow, M. (2002). Index for inclusion: Developing learning and participation in schools ( $2^{\text {nd }}$ ed.). Manchester, England: CSIE

Braddock, J. H., \& Slavin, R. E. (1992). Why ability grouping must end: Achieving excellence and equity in american education. Baltimore, USA: Center for Research on Effective Schooling for Disadvantaged Students.

Bruner, J. S. (1996). The culture of education. USA: Library of Congress Cataloging-inPublication.

Carpenter, L. B., \& Dyal, A. (2007). Secondary inclusion: Strategies for implementing the consultative teacher model. Education, 127(3), 344. 
Cazden, C. B. (1991). El discurso en el aula: El lenguaje de la enseñanza y del aprendizaje. Barcelona, España: Paidós.

Cole, C.M., Waldron, N., \& Majd, M. (2004). Academic progress of students across inclusive and traditional settings. Mental Retardation 42(2), 136-44.

Echeita, G., \& Ainscow, M. (2011). La educación Inclusiva como derecho: Marco de referencia y pautas de acción para el desarrollo de una revolución pendiente. Conferencia presentada en Congreso Iberoamericano sobre Síndrome de Down. Granada, España.

Edwards, D., \& Mercer, N. (1988). El conocimiento compartido: El desarrollo de la comprensión en el aula. Barcelona, España: Paidós.

Eisenman, L. T., Pleet, A. M., Wandry, D. \& McGinley, V. (2010). Voices of special education teachers in an inclusive high school: Redefining responsibilities. Remedial and Special Education, 32(2), 91-104. doi: 10.1177/0741932510361248

Authors. (2005). [details removed for peer review]

European Union. (2010). Charter of fundamental rights of the European Union. Official Journal of European Union, 389-403.

Authors. (2013). [details removed for peer review]

Giné, C., Duran, D., Font, J., \& Miquel, E. (2009). La educación Inclusiva: De la exclusión a la plena participación de todo el alumnado. Barcelona, España: I.C.E. - Horsori.

Gómez, A., Elboj, C., \& Capllonch, M. (2013). Beyond Action Research. The Communicative Methodology of Research. International Review of Qualitative Research, 6(2), 183-197.

Gómez, J., Latorre, A., Sánchez Aroca, M., \& Flecha, R. (2006). Metodología comunicativa crítica. Esplugues de Llobregat, España: El Roure.

Gómez, A., Puigvert, L., \& Flecha, R. (2011). Critical Communicative Methodology:informing Real Social Transformation Through Research. Qualitative Inquiry, 17, 235-245.

Graden, L., \& Bauer, M. (2004). Enfoque colaborativo para apoyar al alumnado y profesorado de aulas inclusivas. In S. Stainback \& W. Stainback (Eds.), Aulas inclusivas (pp.103-117). Madrid, España: Narcea

Griffin, C.C., Kilgore, K. L., Winn, J. A., \& Otis-Wilborn, A. (2008). First-year special educators' relationships with their general education colleagues. Teacher Education Quaterly, 35(1), 141-157.

Gurgur, H., \& Uzuner, Y. (2011). Examining the implementation of two co-teaching models: Team teaching and station teaching. International Journal of Inclusive Education, 15(6), 589-610. doi: 10.1080/13603110903265032 
Hargreaves, D. (1979). Las relaciones interpersonales en la educación. Madrid: Narcea S.A.

Hodge, N., \& Runswick-Cole, K. (2008). Problematising parent-professional partnerships in education. Disability and Society, 23(6), 637-647. doi: 10.1080/09687590802328543

Huguet, T. (2006). Aprendre junts a l'aula: Una proposta inclusiva. Barcelona: Graó.

Kalambouka, A., Farrell, P., Dyson, A., \& Kaplan, I. (2007). The impact of placing pupils with special educational n.e.e.ds in mainstream schools on the achievement of their peers. Educational Research, 49(4), 365-382.

doi: http://doi.org/10.1080/00131880701717222

Knackendoffel, E. A. (2005). Collaborative teaming in the secondary school. Focus on Exceptional Children, 37(5), 1-16.

Lave, J., \& Wenger, E. (1991). Situated learning: Legitimate peripherial participation. New York: Cambridge University Press.

Levin, H. M. (1998). Accelerated schools: A decade of evolution. In A. Hargreaves, et al. (Eds.), International Handbook of Educational Change (807-830). Netherlands: Springer

Lucas, S. R. (2001). Effectively maintained inequality: Education transitions, track mobility, and social background effects. American Journal of Sociology, 106(6), 1642-1690. doi:0002-9602/2001/10606-0004\$02.50

Markussen, E. (2004) Special education: Does it help? A study of special education in Norwegian upper secondary schools. European Journal of Special Needs Education, 19 (1), 33-48. doi 10.1080/0885625032000167133

Mastropieri, M. A., Scruggs, T. E., Graetz, J., Norland, J., Gardizi, W. \& McDuffie, K. (2005). Case studies in co-teaching in the content areas: Successes, failures and challenges. Intervention in Schools and Clinic, 40(5), 260-270. doi: $10.1177 / 10534512050400050201$

Mercer, N. (1997). La construcción guiada del conocimiento: El habla de profesores y alumnos. Barcelona: Paidós.

Muntaner, J., Alzina, P. \& Radó, J. (2006). Organització dels suports. In P. Pujolàs (Ed.) Cap a una educació inclusiva. Crònica d'unes experiències. (37-60). Vic, España: Eumo.

Oakes, J. (1985). Keeping track: How schools structure inequality. New York, NY: Vail-Ballou Press.

O'Brien, P., McConkey, R., \& García-Iriarte, E. (2014). Co-researching with people who have intellectual disabilities: Insights from a national survey. Journal of Applied Research in Intellectual Disabilities, 27(1), 65-75. doi: 10.1111/jar.12074 
Oliver, E., de Botton, L., Soler, M., \& Merril, B. (2011). Cultural intelligence to overcome educational exclusion. Qualitative Inquiry, 17(3), 267-276.

doi: $10.1177 / 1077800410397805$

Orfield, G., Frankenberg, E., \& Siegel-Hawley, G. (2010). Integrated schools: Finding a new path. Educational Leadership, 68(3), 22 -27.

OECD [The Organization for Economic Cooperation and Development] (2012). Education at a glance 2012: OECD Indicators. OECD Publishing. Retrieved on 20 August, 2015 from: doi: http://dx.doi.org/10.1787/eag-2012-en

Authors. (2013). [details removed for peer review]

Porter, G. L., \& Smith, D. (2008). Exploring inclusive educational practices through professional inquiry. Rotterdam: Sense Pub.

Ryder, A. R., Rostas, I., \& Taba, M. (2014). 'Nothing about us without us': The role of inclusive community development in school desegregation for Roma communities. Race Ethnicity and Education, 17(4), 518-539. doi: 10.1080/13613324.2014.885426

Rogoff, B. (1993). Aprendices del pensamiento: El desarrollo cognitivo en el contexto social. Barcelona, España: Paidós.

Russell, P. (2008). 'Building brighter futures for all our children' - a new focus on families as partners and change agents in the care and development of children with disabilities or special educational needs. Support for Learning, 23(3), 104112. doi: $10.1111 / \mathrm{j} .1467-9604.2008 .00380 . x$

Slavin, R. E., Lake, C., Davis, S., \& Madden, N. A. (2011). Effective programs for struggling readers: A best-evidence synthesis. Educational Research Review, 6, 1-26. doi:10.1016/j.edurev.2010.07.002

Stainback, S., \& Stainback, W. (2004). Aulas inclusivas: Un nuevo modo de enfocar y vivir el currículo. Madrid, España: Narcea.

Strogilos, V., \& Tragoulia, E. (2013). Inclusive and collaborative practice roles and responsibilities for teachers and parents. Teaching and Teacher Education, 35, 81-91. doi: 10.1016/j.tate.2013.06.001

Strogilos, V., \& Stefanidis, A. (2015). Contextual antecedents of co-teaching efficacy: Their influence on students with disabilities' learning progress, social participation and behaviour improvement. Teaching and Teacher Education, 47, 218-229. doi: 10.1016/j.tate.2015.01.008

Takala, M., Pirttimaa, R., \& Törmänen, M. (2009). Research section: Inclusive special education: The role of special education teachers in Finland. British Journal of Special Education, 36, 162-173. doi: 10.1111/j.1467-8578.2009.00432.x 
Tutty, C., \& Hocking, C. (2004). A shackled heart: Teacher Aides' experience of supporting students with high needs in regular classes. Kairaranga, 5(2), 3-10.

Valls, R., \& Kyriakides, L. (2013). The power of interactive groups: How diversity of adults volunteering in classroom groups can promote inclusion and success for children of vulnerable minority ethnic populations. Cambridge Journal of Education, 43(1), 17-3. doi :10.1080/0305764X.2012.749213

Vlachou, A. (2006). Role of special/support teachers in Greek primary schools: A counterproductive effect of "inclusion" practices. International Journal of Inclusive Education, 10(1), 39-58. doi: 10.1080/13603110500221586

Vygotski, L. V. (1988). Pensament i llenguatge. Barcelona: Eumo.

Wallace, T., Anderson, A. R., \& Bartholomay, T. (2002). Collaboration: An element associated with the success of four inclusive high schools. Journal of Educational and Psychological Consultation, 13, 349-382.

doi: $\quad$ 10.1207/S1532768XJEPC1304:05

Weiss, M. P., \& LIoyd, J. L. (2002). Congruence between roles and actions of secondary educators in co-taught and special education settings. The Journal of Special Education, 36(2), 58-68. doi: 10.1177/00224669020360020101

Wells, G. (2001). Indagación dialógica: Hacia una teoría y una práctica socioculturales de la educación. Barcelona, España: Paidós. 


\section{Acknowledgements}

This research would not have been possible without the contributions of colleagues from the Seminar on Educational Support: Àngela Castelló, Minerva Díaz, Conxi Escartín, Alba Illa, Montse Imbert, Maria Jornet, Marta Mateu, Rosa Montiel, Laia Muñoz, Silvia Prat, Joana Rodríguez, M. José Segura, Belinda Siles, and Aina Torroella. We must also acknowledge the support provided by the Department of Didactics and Educational Organization (DOE) and the Educational Sciences Institute (ICE) of the University of Barcelona.

This research did not receive any specific grant from funding agencies in the public, commercial, or not-for-profit sectors. 
Table 1

Data collection techniques

\begin{tabular}{|c|c|c|}
\hline $\begin{array}{c}\text { Data Collection } \\
\text { Techniques }\end{array}$ & $\begin{array}{c}\text { Profile of } \\
\text { Participants }\end{array}$ & Number \\
\hline \multirow[t]{2}{*}{ In-depth interviews } & Principal & 2 interviews* \\
\hline & Support teacher & 3 interviews \\
\hline \multirow[t]{3}{*}{ Communicative Discussion groups } & General teachers & 3 discussion groups \\
\hline & Families & 3 discussion groups \\
\hline & Students & 3 discussion groups \\
\hline Document analysis & $\begin{array}{l}\text { Proceedings Seminar } \\
\text { Support Meetings }\end{array}$ & $\begin{array}{l}26 \text { proceedings } \\
\text { reviewed }\end{array}$ \\
\hline
\end{tabular}

(*) Only one could not be completed due to illness.

Table 2

Categories used for the fieldwork analysis

\begin{tabular}{l|l}
\hline \multicolumn{2}{c}{ Categories } \\
\hline $\begin{array}{l}\text { Support Agents } \\
\text { Who they are and what they do }\end{array}$ & Interactions from support teachers \\
With other agents \\
\hline $\begin{array}{l}\text { Assessment of agents' participation } \\
\text { Positive and negative comments }\end{array}$ & Initial and continuing training \\
\hline Organization & Teacher perceptions of \\
From students, teachers, and other agents & Related to support \\
\hline $\begin{array}{l}\text { Organization of support teachers } \\
\text { Ways of support }\end{array}$ & $\begin{array}{l}\text { Information on cases } \\
\text { Precedents, detection, and experiences }\end{array}$ \\
\hline
\end{tabular}




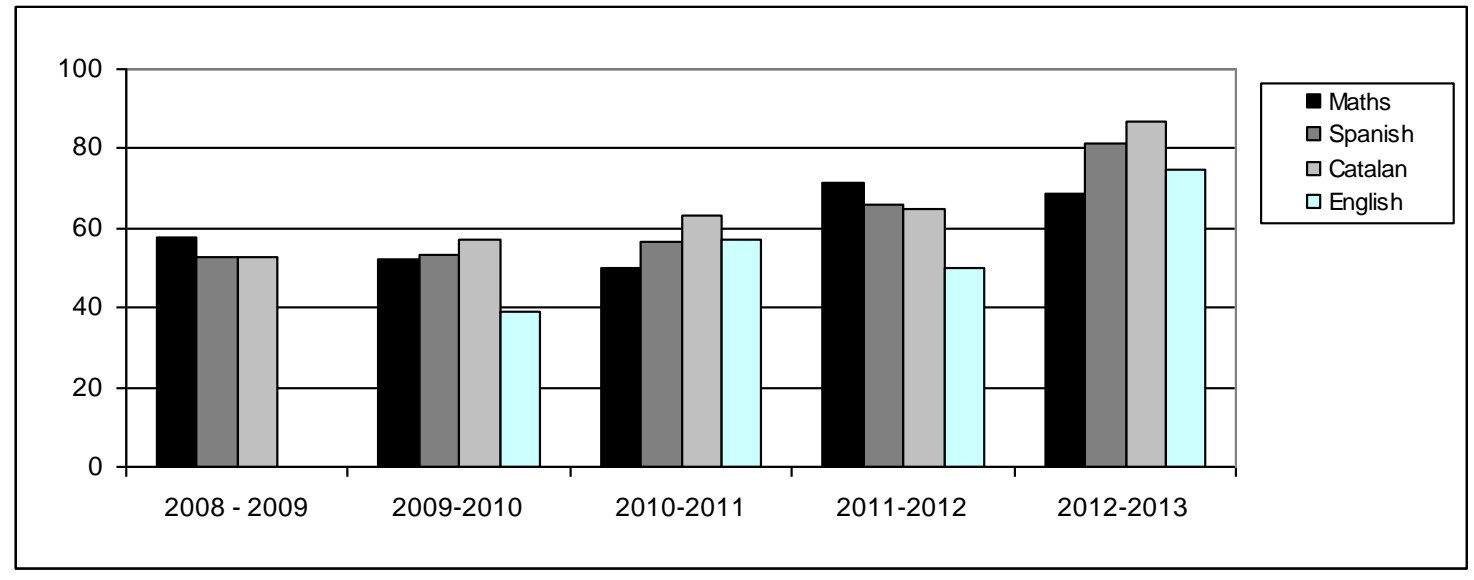

Figure 1: Improvement in external test results in sixth grade from school "L"

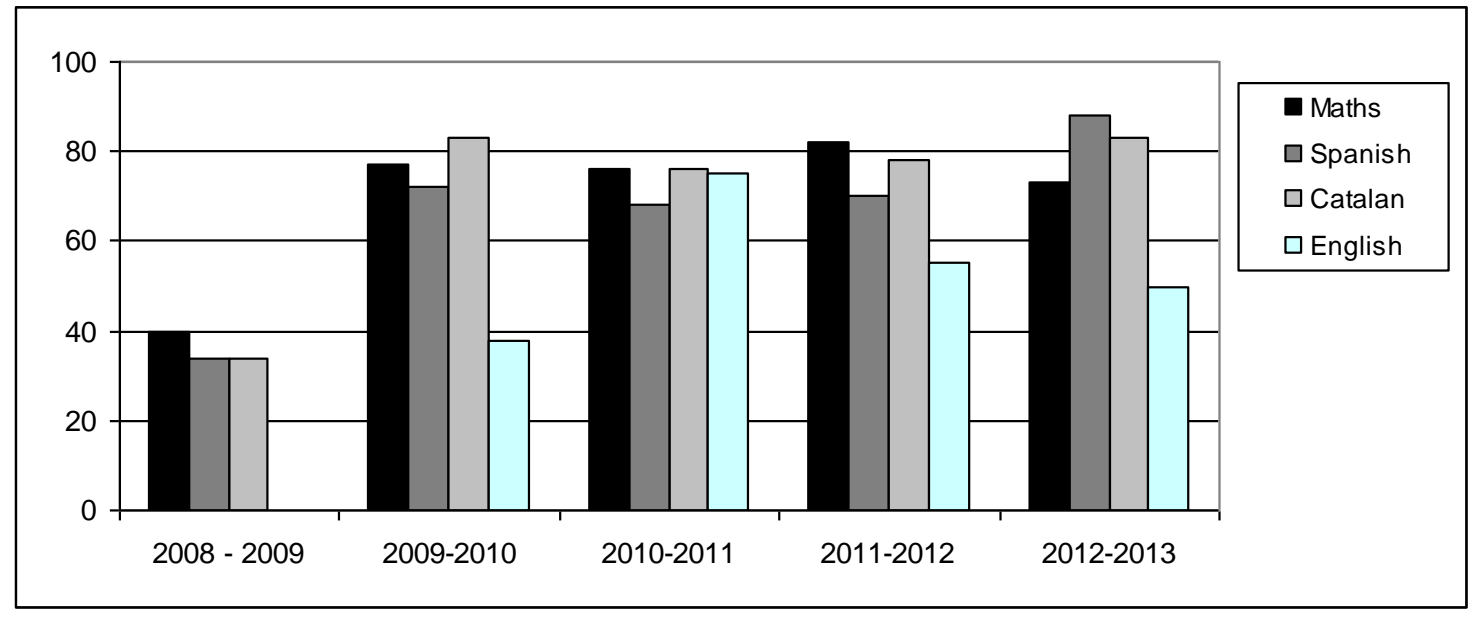

Figure 2: Improvement in external test results in sixth grade from school "A" 